\title{
40. BIOMAGNETOSTRATIGRAPHIC CORRELATIONS FROM LEG 107 IN THE TYRRHENIAN SEA ${ }^{1}$
}

\author{
J.E.T. Channell, ${ }^{2}$ D. Rio, ${ }^{3}$ R. Sprovieri, ${ }^{4}$ and G. Glaçon ${ }^{5}$
}

\begin{abstract}
Correlations of biostratigraphic datums to the geomagnetic reversal time scale (GRTS) at Leg 107 sites provide a means of correlating these datums to sections outside the Mediterranean. Unfortunately, poor recovery and core deformation due to rotary drilling at Sites 651,652 , and 654 severely hampered efforts to acquire detailed magnetostratigraphies and biostratigraphies. However, many biostratigraphic markers could be correlated to the GRTS, including those close to the Miocene/Pliocene and Tortonian/Messinian boundaries. These boundaries are interpreted to occur in Chrons $3 \mathrm{r}$ and $3 \mathrm{~B}$, respectively (chron nomenclature after Cox, 1982). Comparison of the correlation of Plio-Pleistocene calcareous plankton biostratigraphic events to the GRTS in the Mediterranean and in the open oceans indicates that many events are broadly synchronous between the two environments. The outstanding exception is the first occurrence of Globorotalia margaritae which is delayed in the Mediterranean by about $1 \mathrm{~m} . \mathrm{y}$.
\end{abstract}

\section{INTRODUCTION}

The standard chronostratigraphic units of the late Neogene were introduced with reference to marine land sections in Italy, where all the stratotype sections are located. Correlation of paleontological and other stratigraphic events from the Mediterranean Neogene to the open ocean is therefore critical to global Neogene stratigraphy, and has not been satisfactorily accomplished. The problem of direct biostratigraphic correlation from the Mediterranean to the open ocean is hindered by the provincial distribution of the Mediterranean foraminiferal assemblages and, to a lesser extent, the nannofossil assemblages. In addition, some biostratigraphic markers are apparently immigrants into the Mediterranean, their first occurrences being delayed with respect to their appearance in the open ocean. Rio et al. (1984) have analyzed the ranking and spacing of Pliocene and lower Pleistocene calcareous plankton biostratigraphic events in the Mediterranean, comparing them with the succession of events in the open ocean using Shaw Diagram techniques. This approach has led to an improved evaluation of the absolute age of Plio-Pleistocene biostratigraphic events within the Mediterranean, and has facilitated their global correlation. However, the key to further progress is magnetostratigraphy. Geomagnetic polarity reversals are the only frequent synchronous events recorded in sedimentary sequences, and for the Plio-Pleistocene the absolute ages of the reversal boundaries are well constrained (e.g., Berggren et al., 1985; Cox, 1982). Our goal in this paper is to review the available correlations of Neogene biostratigraphic events to the geomagnetic reversal time scale (GRTS), and in so doing make an evaluation of the timing of biostratigraphic events, and assess their usefulness for correlation between the Mediterranean and the open ocean.

Until a few years ago, there were no reliable magnetostratigraphies from the Mediterranean Neogene. The compilation of Ryan et al. (1974) was based on the controversial, and now obsolete, magnetostratigraphies of Ryan and Flood (1972) and

\footnotetext{
${ }^{1}$ Kastens, K. A., Mascle, J., et al., 1990. Proc. ODP, Sci. Results, 107: College Station, TX (Ocean Drilling Program).

2 Department of Geology, University of Florida, Gainesville, FL 32611.

3 Istituto di Geologia, Universita di Parma, 43100, Parma, Italy.

${ }^{4}$ Istituto di Geologia, Universita di Palermo, 90100 Palermo, Italy.

5 Laboratoire de Stratigraphie et de Paléocologie, Université de Provence, 13331 Marseille, France.
}

Nakagawa et al. (1974, 1977). The first useful magnetostratigraphy from the Mediterranean Neogene was that of Tauxe et al. (1983a) who provided a magnetostratigraphy for the Plio-Pleistocene type section at Vrica (Calabria). Subsequently, Zijderveld et al. (1986) and Channell et al. (1988) obtained high quality magnetostratigraphic control for the lower Pliocene in Calabria (Italy), and Langereis et al. (1984) have obtained a high quality, albeit controversial, magnetostratigraphy from the late Miocene in Crete. Leg 107 provided an opportunity to obtain sorely needed additional magnetostratigraphic control for the Mediterranean Neogene.

\section{MATERIALS AND METHODS}

\section{Magnetostratigraphy}

The Leg 107 magnetostratigraphies are almost entirely based on rotary cores. The priorities of Leg 107 were such that only Sites 650 and 653 (Fig. 1) were drilled using the APC/XCB technique. The sedimentary sequence recovered at Site 650 was largely Pleistocene in age, and Site 653 did not yield a magnetostratigraphy due to adverse magnetic properties at this Site (Channell, Hawthorne, and Torii, this volume). The quality of the magnetostratigraphic records at Sites 651, 652, and 654 (Fig. 1) is severely compromised by the use of the rotary drilling technique. Not only does rotary drilling result in poor recovery and core disturbance, but also gives rise to a steeply inclined magnetic overprint, apparently imparted by the drill-string, which is not easily removed. The overprint has sufficiently high coercivity that the shipboard long-core cryogenic magnetometer/demagnetizer could not be used to resolve the primary component, as the peak allowable alternating demagnetizing field $(8 \mathrm{mT})$ was insufficient to obliterate the overprint. The polarity determinations are based on inclination data from thermally demagnetized subsamples (see Channell, Torii, and Hawthorne, this volume).

\section{Biostratigraphy}

The biostratigraphy of Leg 107 cores was carried out by a number of independent workers. In our summary diagrams (Figs. 2-5), we do not attempt to reconcile discrepancies but rather to illustrate where these discrepancies occur. Müller (this volume) utilized the zonation of Martini (1971). The nannofossil data for Sites 650 and 651 (Figs. 2 and 3) are based entirely on the work of Müller (this volume). For Sites 652 and 654 (Figs. 4 and 5), both the Martini (1971) zonation (Müller, this volume), and the alternative zonation of Raffi and Rio (1979) emended by Rio et al. (this volume) are presented (Glaçon et al., this volume). The nannofossil events for Sites 652 and 654 (Figs. 4 and 5) are from Rio (in Glaçon et al., this volume). Comparison of Columns A and B in Figures 4 and 5 with the theoretical correlation of the two zonal schemes (Fig. 6) illustrates the magnitude of the discrepancies. These are discussed below. 


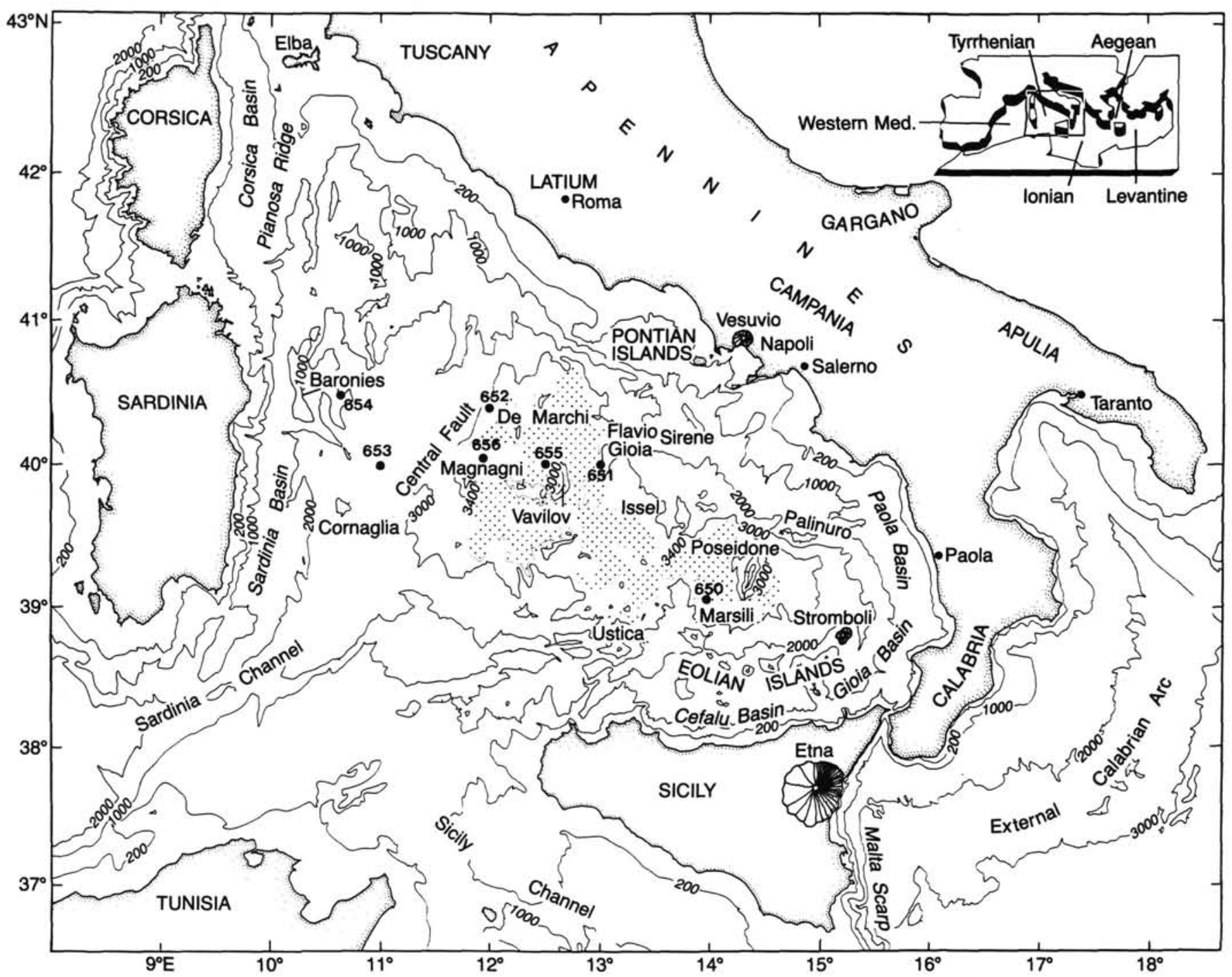

Figure 1. Location of relevant sites from Leg 107 of the Ocean Drilling Project (base map after Rehault et al., 1987).

The planktonic foraminiferal zonations (zonation after Cita, 1975; emended by Rio et al., 1984) and the foraminiferal ranges for Sites 652 and 654 (Figs. 4 and 5) are after Glaçon et al. (this volume). The benthic foraminiferal zonations (Figs. 4 and 5) are from Sprovieri and Hasegawa (this volume).

\section{Isotopic Stages}

For Site 650 (Fig. 2) the inferred oxygen isotopic stages are based on two independent data sets. Column " $\mathrm{A}$ " in Figure 2 is based on the interpretation of the isotopic curve (Vergnaud Grazzini et al., this volume). The isotopic curve has low resolution at this site, and the recognition of "cold" and "warm" planktonic foraminiferal assemblages provides a means of independently checking the isotopic chronology. In Column "B" (Fig. 2), the planktonic foraminiferal record has been interpreted in terms of isotopic stages (Glaçon, unpubl. data). This process has been aided by correlation of these assemblages to the more detailed isotopic and biostratigraphic record at Site 653.

\section{SITE 650}

There are several points which should be made in reference to the biomagnetostratigraphic correlations at Site 650 (Fig. 2). Globorotalia truncatulinoides excelsa is extremely rare in all samples, therefore its first occurrence (FO) is unreliable and its coincidence with the Jaramillo subchron confirms this supposi- tion, as its Mediterranean FO usually occurs below this level (Rio et al., in press). The first appearance of Emiliania huxleyi is also poorly defined due to difficulties in recognizing this species with the optical microscope. The small Gephyrocapsa zone usually ends within the Jaramillo (Rio, 1982; Berggren et al., 1985), and its extension above the Jaramillo at this site is anomalous. This is probably due to the inherent difficulties associated with the recognition of this zone (see Rio et al., this volume). The last appearance datum (LAD) of Cyclococcolithus (Calcidiscus) macintyrei is used here as a marker of the NN18/ NN19 boundary because the standard marker for this zonal boundary ( $D$. brouweri) is rare or absent at the base of the hole. It has been shown both in the open ocean (Backman and Shackleton, 1983) and in the Mediterranean (Rio et al., this volume) that the LAD of Cyclococcolithus (Calcidiscus) macintyrei occurs within NN19.

The foraminiferal events give us a more precise chronology at the base of this hole, close to the Plio-Pleistocene boundary. The increase in abundance of left-coiling $N$. pachyderma marks the top of MPL6 and the Plio-Pleistocene boundary. The first appearance of $G$. cariacoensis and Articulina tubulosa, as well as the LAD of $G$. obliquus extremus also lie close to the PlioPleistocene boundary. 


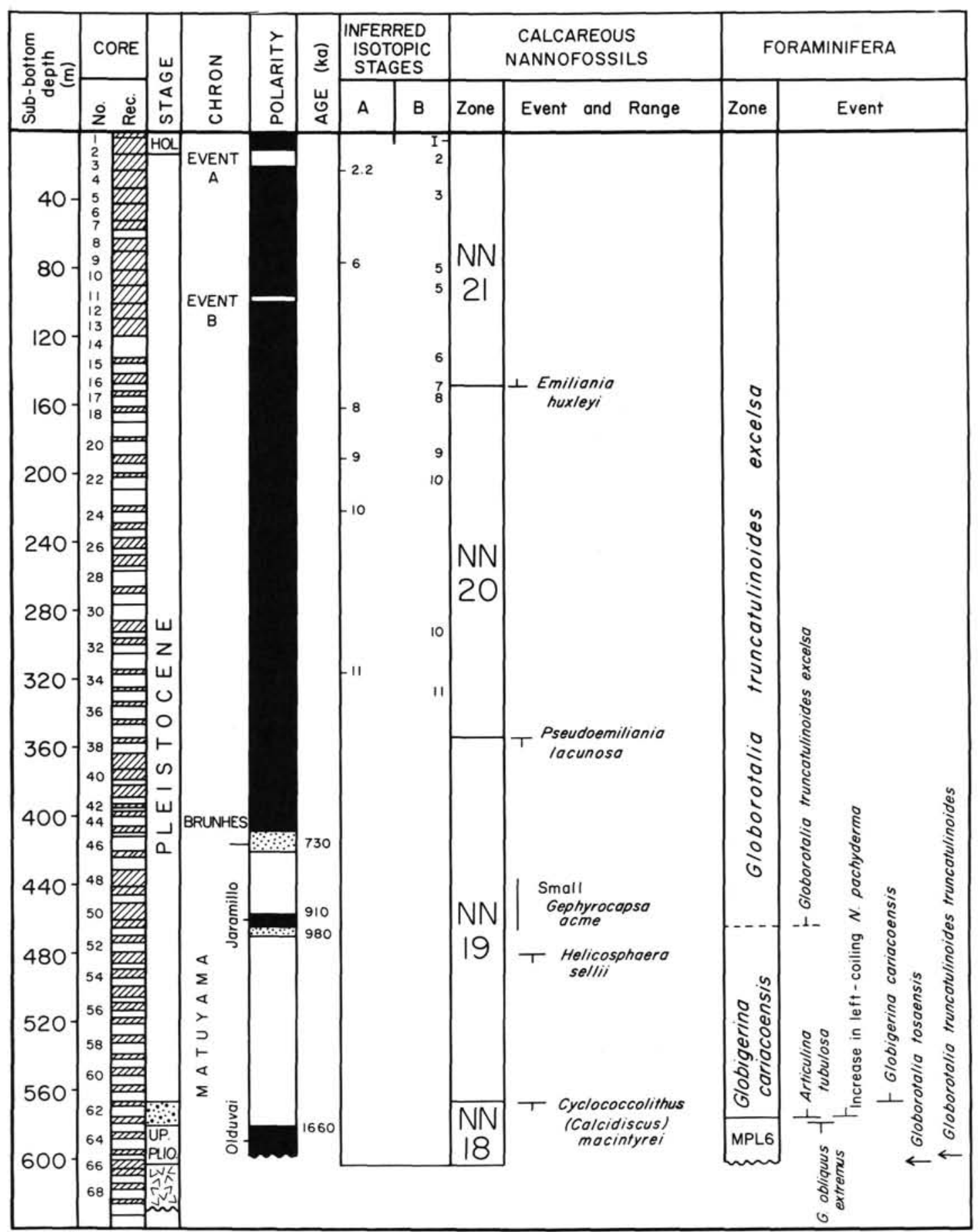

Figure 2. Correlation chart for Site 650. Magnetostratigraphy after Channell, Torii, and Hawthorne (this volume). Inferred isotopic stages after Vergnaud Grazzini et al. (this volume) (Column A), and Glaçon (unpubl. data) (Column B). Nannofossil stratigraphy after Müller (this volume).

The oxygen isotopic chronologies (Fig. 2) are inferred from the isotope curve itself (column A), and independently from study of the foraminiferal assemblages (column B) (Vergnaud Grazzini et al., this volume; Glaçon, unpubl. data). The turbiditic nature of the sediments is such that both methods are compromised by problems of reworking. However, these inferred isotopic chronologies become important for providing age constraints for "Event A" and "Event B" in the magnetic record (Channell and Torii, this volume). "Event A" appears to lie in Stage 2, and "Event B" in either Stage 5 or Stage 6. The "in situ" foraminiferal assemblage close to "Event B" indicates "warm" conditions correlative to Stage 5, with reworking of foraminifera correlative to Stage 6 (Glaçon, unpubl. data). We suspect that the isotopic curve itself (column A) may be reflecting the reworking, and we tentatively assign "Event B" to Stage 5 .

From a chronostratigraphic point of view, the correlation of the Plio-Pleistocene boundary and the correlative foraminiferal events to top of the Olduvai subchron is one of the major contributions of this hole. This correlation is consistent with the re- 


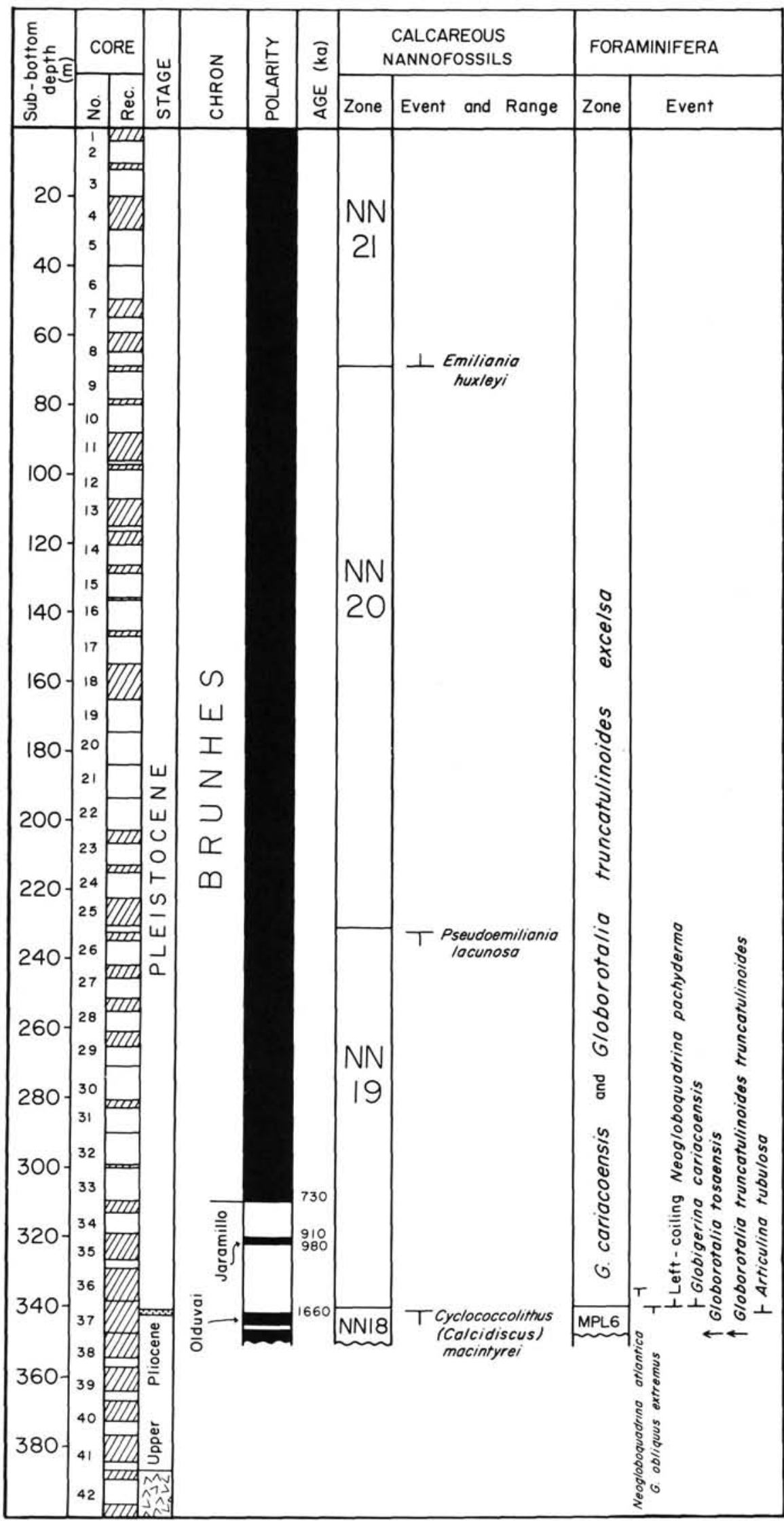

Figure 3. Correlation chart for Site 651. Magnetostratigraphy after Channell, Torii, and Hawthorne (this volume); nannofossil stratigraphy after Müller (this volume). 


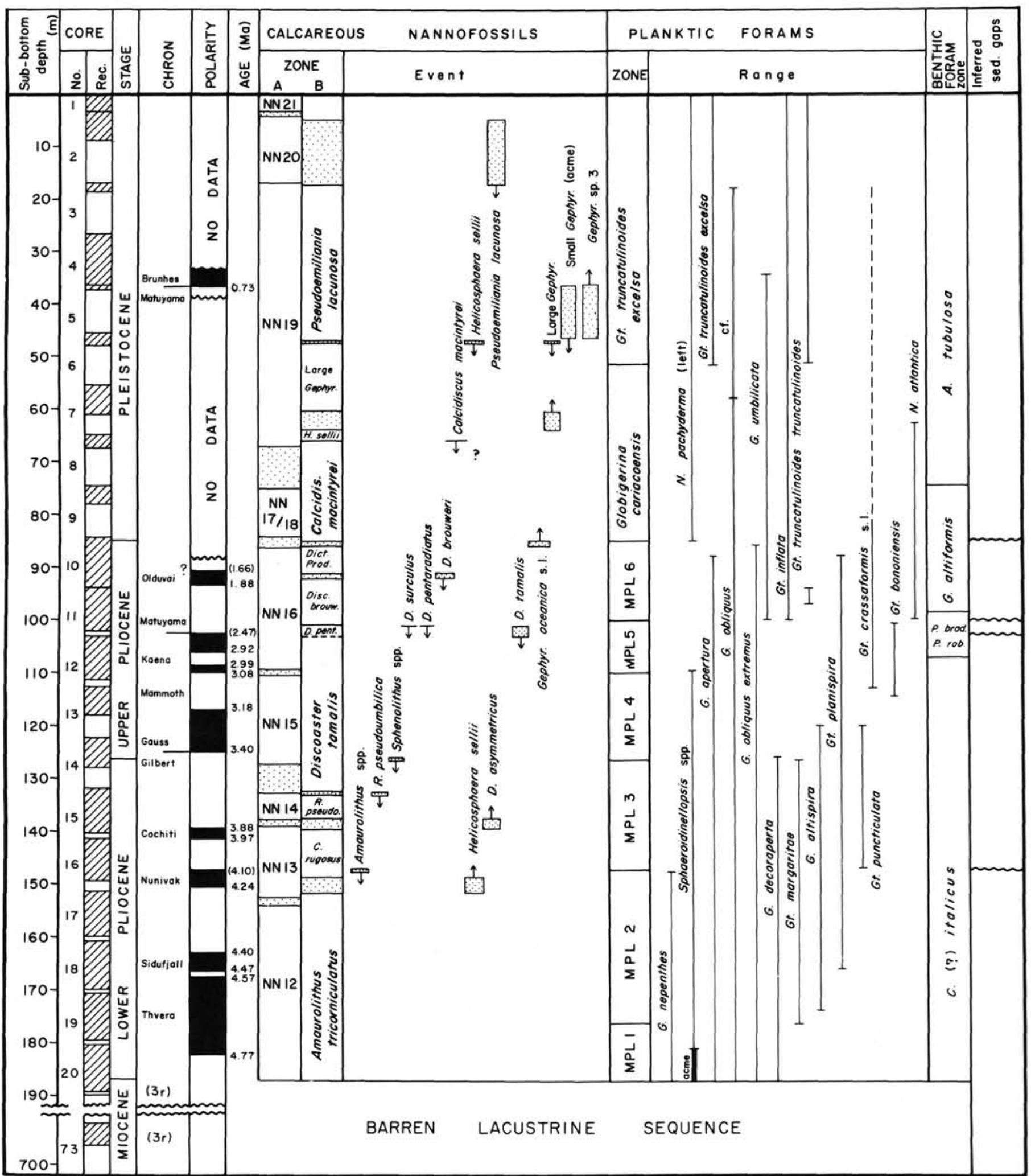

Figure 4. Correlation chart for Site 652. Magnetostratigraphy after Channell, Torii, and Hawthorne (this volume). Nannofossil zonations: Column A after Müller (this volume); Column B after Glaçon (this volume). Nannofossil and foraminiferal events and planktonic foraminiferal zonation after Glaçon (this volume). Benthic foraminiferal zonation after Sprovieri and Hasegawa (this volume). 


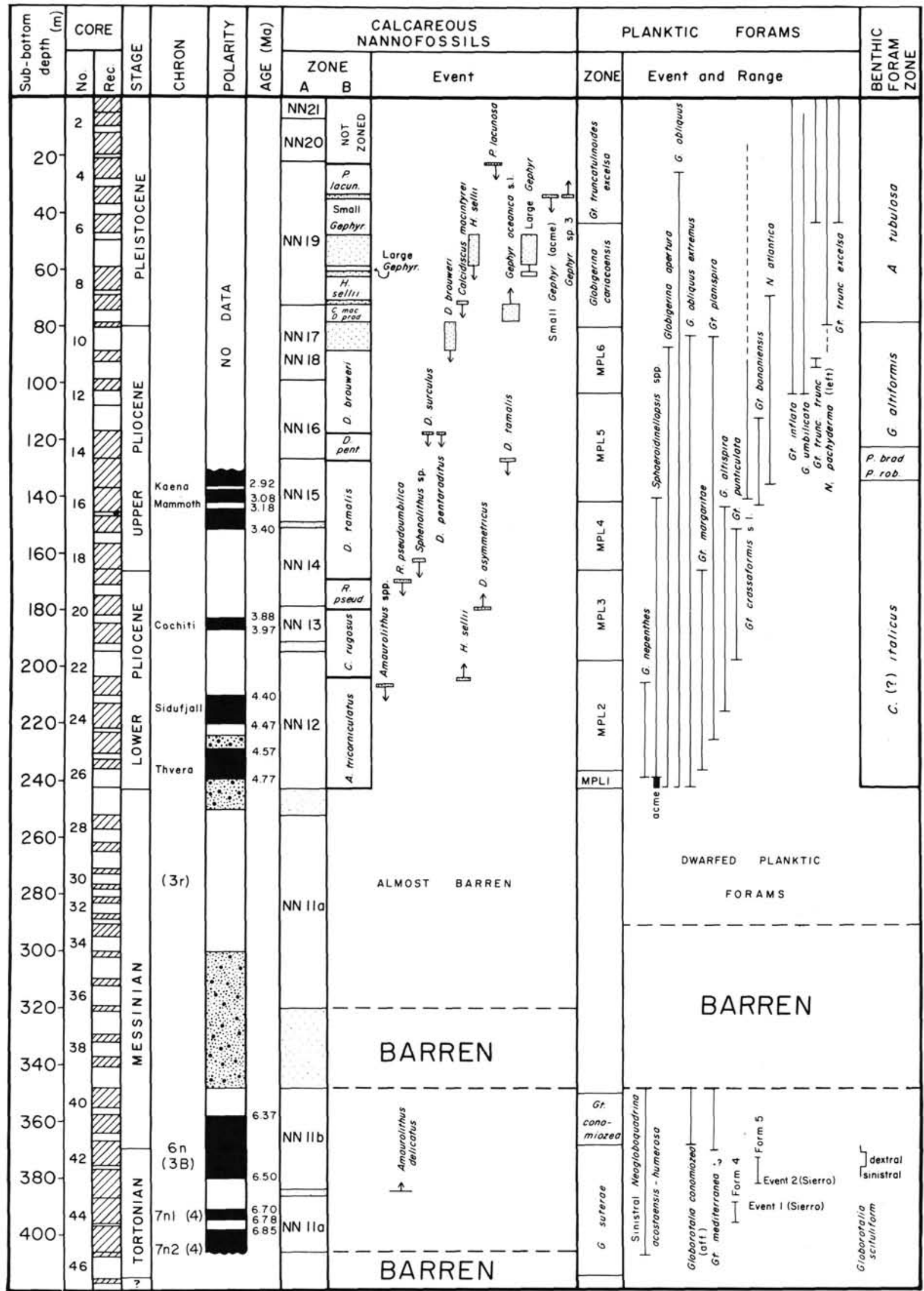

Figure 5. Correlation chart for Site 654. Magnetostratigraphy after Channell, Torii, and Hawthorne (this volume). Nannofossil zonations: Column A after Müller (this volume); Column B after Glaçon et al. (this volume). Nannofossil and foraminiferal events and planktonic foraminiferal zonation after Glaçon et al. (this volume). Benthic foraminiferal zonation after Sprovieri and Hasegawa (this volume). 


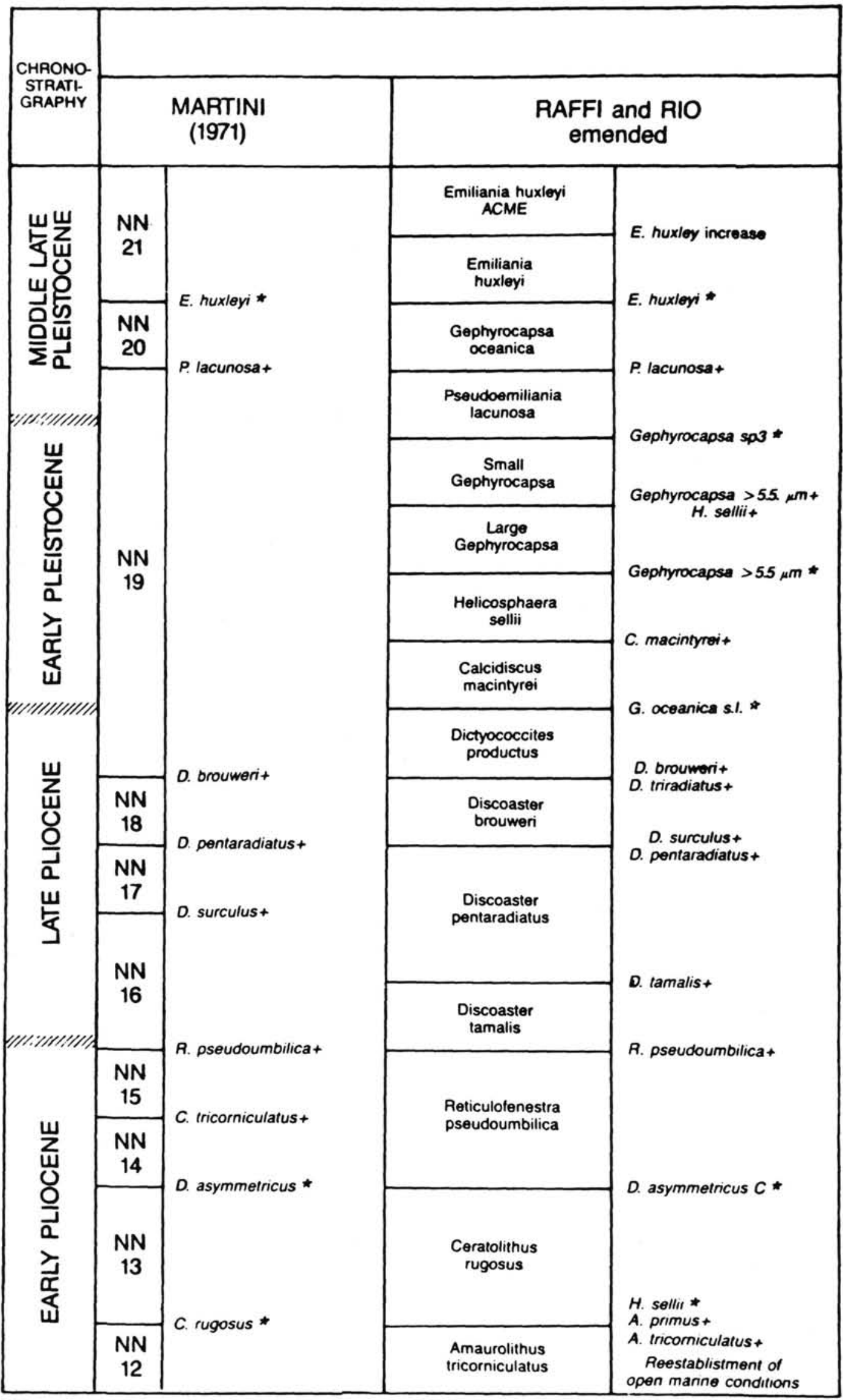

Figure 6. Correlation of the nannofossil zonation of Martini (1971) with that of Raffi and Rio (1979) emended by Rio et al. (this volume). 
sult from the stratotype section for the Plio-Pleistocene boundary at Vrica (Tauxe et al., 1983a).

\section{SITE 651}

The rotary drilling technique resulted in poor recovery and core disturbance in Site 651. The recovery is improved close to the Plio-Pleistocene boundary (Fig. 3). As in Hole 650, the FAD of Emiliania huxleyi is poorly defined, but here the problem is exacerbated by poor recovery. The FO of Globorotalia truncatulinoides excelsa cannot be adequately defined at this site, and the base of the biozone is not marked. The increased abundance of left-coiling N. pachyderma marks the Plio-Pleistocene boundary, and this datum is coincident with the first appearance of $G$. cariacoensis and Articulina tubulosa, and with the LAD of $G$. obliquus extremus. As in Hole 650, the LAD of Cyclococcolithus (Calcidiscus) macintyrei is used as a marker for the NN18/NN19 boundary. As mentioned above, this is an unorthodox practice and was adopted due to the paucity of the standard marker ( $D$. brouweri) (Müller, this volume). In conclusion, the principal biomagnetostratigraphic correlation at Site 651, is that of the Plio-Pleistocene boundary markers to the top of the Olduvai subchron.

\section{SITE 652}

At Site 652 , there are a number of obvious discrepancies between the two nannofossil zonations (cf., Columns A and B in Figs. 4 and 5) given by Müller (this volume) and Rio (in Glaçon et al., this volume). Such discrepancies seem to be derived from differing taxonomic concepts, different data collection procedures (quantitative vs. nonquantitative), and different operational definitions of the biostratigraphic events. This last point is particularly critical and concerns whether the biostratigraphic event is defined by a first or last absolute occurrence, or by the distinct rise or fall in abundance (see Backman and Shackleton, 1983).

The top of NN15 (Column A, Fig. 4) which is usually defined by the LAD of $R$. pseudoumbilica, should coincide with the top of the $R$. pseudoumbilica zone of the Raffi and Rio (1979) (Column B) (see Fig. 6). This discrepancy may be due to the taxonomic problem associated with the definition of this species (see Rio et al., this volume). The top of NN16 which is usually defined by the LAD of $D$. surculus appears to be strongly inconsistent between the two zonations. We believe that this is due to reworking of this species above the true LAD. Similarly, the top of NN18, which is defined by the LAD of $D$. brouweri, is marked as being well above the LAD given by Rio (in Glaçon et al., this volume).

A comparison of the two discrepant nannofossil zonations with the foraminiferal and magnetostratigraphic data at the other Leg 107 sites and in Mediterranean land sections, provides us with a means of determining which of the two nannofossil zonations is more reliable. For example, the zonal scheme in Column A (Fig. 4) implies that the $R$. pseudoumbilica LAD (top of NN15) occurs near the top of MPL4, close to the Sphaeroidinellopsis spp. $\mathrm{LAD}$, and in the positive polarity interval below the Kaena subchron. This is inconsistent with other Mediterranean sections (Rio et al., 1984) where the $R$. pseudoumbilica LAD occurs near the top of MPL3 and in the upper part of the Gilbert Chron (Gela Section, Channell et al., 1985). The zonal scheme in Column A (Fig. 4) also implies that the D. surculus LAD (top of NN16) coincides with the first common occurrence (FCO) of $N$. pachyderma (left), and therefore to the Plio-Pleistocene boundary. This is inconsistent with all other Mediterranean sections, where the $D$. surculus LAD occurs in the upper part of the MPL5 (Rio et al., 1984) and close to Gauss/Matuyama boundary (Channell et al., 1985). According to the zonal scheme of Column A, the D. brouweri LAD (top of
NN18) lies well within the range of $N$. pachyderma (left), and therefore within the Pleistocene. This is inconsistent with all other Mediterranean sections (Tauxe et al., 1983a; Channell et al., 1985).

These and several other less remarkable inconsistencies between the two nannofossil zonations, given Figures 4 and 5, when compared to each other and to the magnetostratigraphy and foraminiferal events, lead us to adopt the zonations given in Column B (Figs. 4 and 5). The nannofossil events in these two figures are the basis for the zonation in Column B.

The biostratigraphy, together with the magnetostratigraphy, allow the recognition of several stratigraphic gaps at Site 652 (Figs. 4 and 7). The first appearance of Globorotalia puncticulata occurs at the very top of the Nunivak subchron, as does the LAD of $G$. nepenthes. The coincidence of these two events, and their occurrence at the top of the Nunivak suggests a sedimentary gap at this level. Sedimentary gaps in this interval may account for the condensation of MPL3 relative to MPL2. Another sedimentary gap is present between the top of Kaena subchron and the top of the Gauss chron. This gap eliminated the lowest occurrence of N. atlantica, which is recognized in Hole 653A below the LAD of $D$. tamalis. The coincident disappearance of $D$. surculus and $D$. pentaradiatus located only about 1 $\mathrm{m}$ above the LAD of $D$. tamalis, also indicate the presence of a sedimentary gap in this interval. Another sedimentary gap is present between the local disappearance of Globorotalia bononiensis and the appearance of Globorotalia inflata. This gap eliminated the first appearance of Globorotalia inflata, as shown by the very short interval between the two events and between the Globorotalia inflata $\mathrm{FO}$ and the $D$. surculus and $D$. pentaradiatus LADs. These two stratigraphic gaps above the Kaena subchron explain the very reduced thickness of the MPL5 biozone. Another sedimentary gap is present just below the PlioPleistocene boundary. At Vrica, Capo Rossello, and at Site 654, the first peak of $N$. pachyderma (left) predated the appearance of $G$. oceanica. The coincidence of these two events at Site 652 suggests the presence of a short stratigraphic gap.

\section{SITE 654}

At this Site, several long gaps in recovery make it difficult to obtain good correlations and estimates of the ages of particular datum levels (Figs. 5 and 8). The appearance of Globorotalia margaritae within the Thvera subchron is consistent with Site 652. At Site 654, the $G$. nepenthes LAD and the Globorotalia puncticulata LAD are not well defined due to poor recovery in Core 22R (Fig. 5). Both events occur in the Nunivak subchron at Site 652 , and this subchron appears to have been lost in the low recovery interval. Many of the other foraminiferal events such as the LADs of Globorotalia puncticulata, Sphaeroidinellopsis spp., and Globorotalia bononiensis are consistent with the results from Site 652 .

As at Site 652, there are a number of discrepancies between the two nannofossil zonations. We can use the same reasoning as at Site 652 to show that the distribution of planktonic foraminiferal events, and the magnetic stratigraphy, are clearly more consistent with the zonation given in Column B (Fig. 5), than that in Column A. We therefore adopt the zonation given in Column B for the discussion of late Neogene Mediterranean biochronology in the next section of this paper.

The Messinian at Site 654 is characterized by rare nannofossils and dwarfed planktonic foraminifera (Fig. 5). The rare occurrence of Amaurolithus delicatus indicates the NN11b nannofossil zone. Below Core $39 \mathrm{R}$, the microfaunal assemblage is more indicative. The more open marine conditions afford a well defined first appearance datum (FAD) for Amaurolithus delicatus marking the NN11a/NN11b zonal boundary (Müller, this volume). 


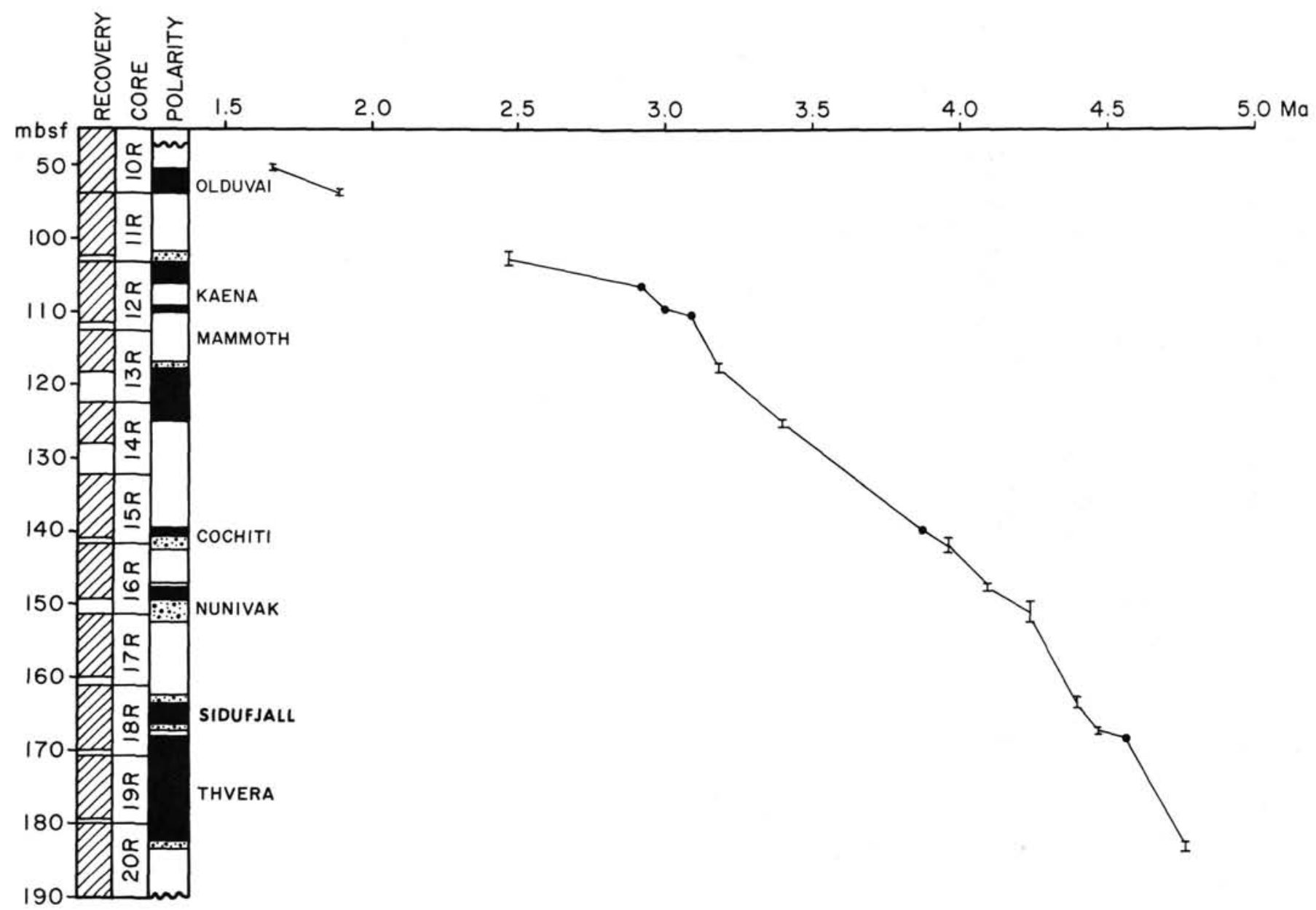

Figure 7. Sedimentation rate curve for Site 652 based on the magnetostratigraphy.

The first appearance of Globorotalia conomiozea has been proposed as the marker for the Tortonian/Messinian boundary (Colalongo et al., 1979) (Fig. 5). The upper boundary of the Globorotalia conomiozea biozone (D'Onofrio et al., 1975) defined by Iaccarino and Salvatorini (1982) as "the coiling shift from sinistral to dextral of Neogloboquadrina acostaensis," is not found at Site 654. The evolution toward restricted marine conditions may therefore have begun before that time, or there may be a hiatus. Research by Glaçon, Iaccarino, Sierro, and Weaver permit us to recognize several events of late Tortonian age (Table 1). These events have previously been identified in Morocco (Feinberg and Lorenz, 1970; Wernli, 1980; Bossio et al., 1976), in Crete (Zachariasse, 1975), and in Spain (Tjalsma, 1971; Sierro, 1985). It is important to note that the inflated phenotypes of the Globorotalia conoidea-Globorotalia miotumida group (named Globorotalia conomiozea in the Mediterranean) appear in the Tyrrhenian earlier, at $6.44 \mathrm{Ma}$ (Table 1), than the first evolutionary appearance of Globorotalia conomiozea sensu stricto in the southwest Pacific dated at 6.1 Ma (Berggren et al., 1985). This supports the doubts of Scott (1980) and Zachariasse (1979) about the occurrence of Globorotalia conomiozea sensu stricto in the Mediterranean. Event 3b (Table 1), clearly recognized in the Mediterranean, could be more useful than "Globorotalia conomiozea" FO as a biostratigraphic datum, at least in the Mediterranean region.

The polarity zone pattern in the Tortonian and early Messinian at Site 654 tends to favor a correlation to Chron 6 and the top of Chron 7 (Chrons 3B and 4 in the nomenclature of Cox,
1982) (Channell, Torii, and Hawthorne, this volume). This correlation implies an age of about $6.44 \mathrm{Ma}$ for the Tortonian/ Messinian boundary.

\section{CORRELATION OF LATE MIOCENE-PLIOCENE BIOSTRATIGRAPHIC EVENTS WITHIN THE MEDITERRANEAN AND TO THE OPEN OCEAN}

In this section, we comment briefly on the age and correlation of the main calcareous plankton events relevant to Late Miocene and Pliocene chronostratigraphy. We have selected biostratigraphic records, both from Mediterranean and extra-Mediterranean regions, which are directly correlative to a magnetostratigraphic record, and hence to the GRTS. The correlations are summarized in Figure 9. The Pleistocene events are not considered since their absolute age is best evaluated by correlation with oxygen isotope stratigraphy. The polarity chron nomenclature used below follows the traditional nomenclature used by Berggren et al. (1985), with the nomenclature of Cox (1982) given in brackets.

1. Amaurolithus spp. (Amaurolithus delicatus) FAD (NN11a-NN11b boundary): This event is well defined at Site 654 and correlates to the basal reversed interval of Chron 6 (Chron 3Br) (Fig. 5). This is the first correlation of this event to the GRTS in the Mediterranean, and indicates a slightly earlier FAD than in the Pacific where it occurs in Chron 6n (Chron 3B) (Haq and Takayama, 1984). 


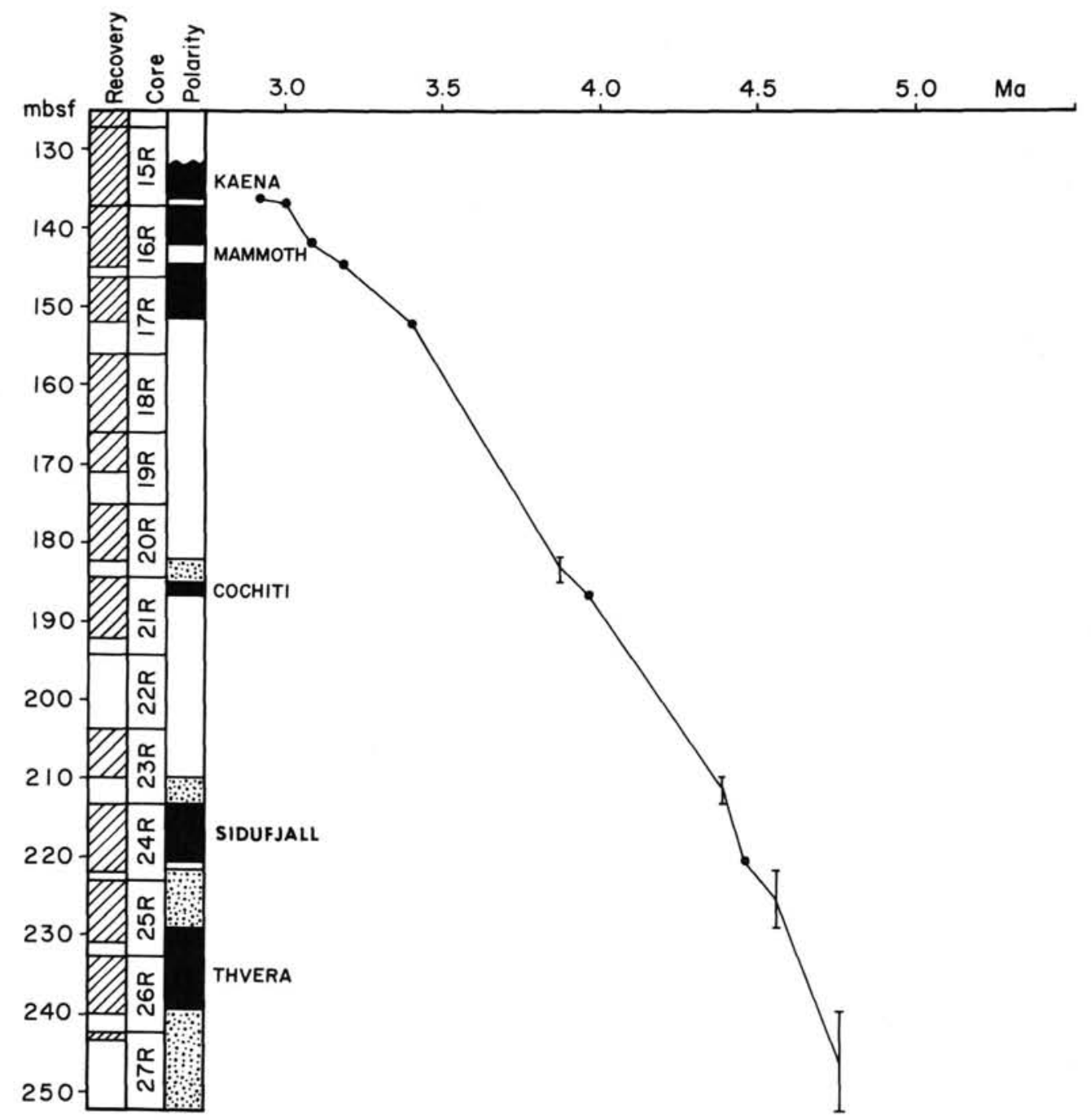

Figure 8 . Sedimentation rate curve for Site 654 based on the magnetostratigraphy.

Table 1. Biostratigraphic events close to the Tortonian-Messinian boundary at Site 654. Ages of events are based on the magnetostratigraphy.

\begin{tabular}{|c|c|c|c|c|}
\hline $\begin{array}{l}\text { Core } \\
\text { interval } \\
(\mathrm{cm})\end{array}$ & $\begin{array}{l}\text { Depth } \\
\text { interval } \\
\text { (mbsf) }\end{array}$ & Event & & $\begin{array}{l}\text { Age } \\
\text { (Ma) }\end{array}$ \\
\hline \multicolumn{5}{|l|}{ Hole $654 \mathrm{~A}$ - } \\
\hline $\begin{array}{l}\text { From } 42 R-2,80-82 \\
\text { To } 42 R-2,90-92\end{array}$ & $\begin{array}{l}369.71 \\
369.81\end{array}$ & $\begin{array}{l}\text { Inflated phenotypes appear in } \\
\text { the } G \text {. conoidea-G. miotu- } \\
\text { mida group (" } G \text {. conomio- } \\
\text { zea" FO) }\end{array}$ & & 6.44 \\
\hline $\begin{array}{l}42 R-3,82-84 \\
42 R-3,90-92\end{array}$ & $\begin{array}{l}371.23 \\
371.31\end{array}$ & $\begin{array}{l}\text { Expansion of the plano-convex } \\
\text { Globorotalia conoidea- } \\
\text { Globorotalia miotumida } \\
\text { group }\end{array}$ & Event $3 \mathrm{~b}$ & 6.45 \\
\hline $\begin{array}{l}42 \mathrm{R}-5,36-38 \\
42 \mathrm{R}-5,82-84\end{array}$ & $\begin{array}{l}373.77 \\
374.23\end{array}$ & $\begin{array}{l}\text { Dextral to sinistral change in the } \\
\text { unkeeled Globorotalids }\end{array}$ & Event B & 6.46 \\
\hline $\begin{array}{l}42 \mathrm{R}-5,90-92 \\
42 \mathrm{R}-6,36-38\end{array}$ & $\begin{array}{l}374.31 \\
375.27\end{array}$ & $\begin{array}{l}\text { Exit of dextral keeled } \\
\text { Globorotalids }\end{array}$ & Event $3 a$ & 6.47 \\
\hline $\begin{array}{l}43 \mathrm{R}-1,60-62 \\
43 \mathrm{R}-1,92-94\end{array}$ & $\begin{array}{l}377.71 \\
378.03\end{array}$ & $\begin{array}{l}\text { Sinistral to dextral change in the } \\
\text { unkeeled Globorotalids }\end{array}$ & Event A & 6.48 \\
\hline $\begin{array}{l}43 R-5,60-62 \\
43 R-5,90-92\end{array}$ & $\begin{array}{l}383.71 \\
384.03\end{array}$ & $\begin{array}{l}\text { Entry of dextral keeled } \\
\text { Globorotalids (Form } 5 \text { of } \\
\text { Zachariasse) }\end{array}$ & Event 2 & 6.56 \\
\hline $\begin{array}{l}44 R-2,92-94 \\
44 R-3,32-34\end{array}$ & $\begin{array}{l}389.23 \\
390.13\end{array}$ & $\begin{array}{l}\text { Exit of sinistral keeled } \\
\text { Globorotalids (Form } 4 \text { of } \\
\text { Zachariasse) }\end{array}$ & Event 1 & 6.7 \\
\hline
\end{tabular}




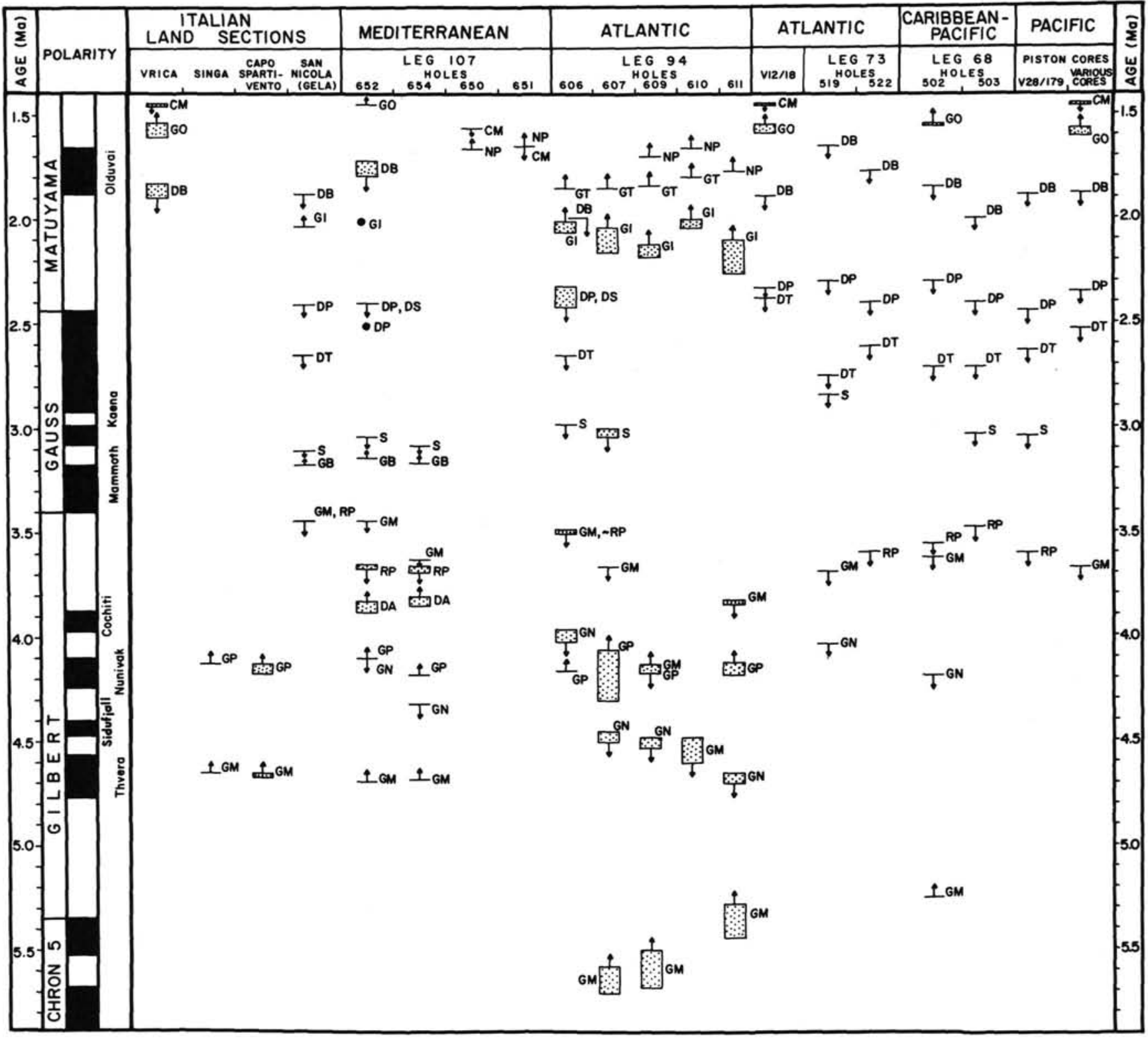

Figure 9. Correlation of various nannofossil and foraminiferal events to the geomagnetic polarity time scale for open ocean cores, and for Leg 107 cores and Mediterranean outcrops. Only those records with good magnetostratigraphic and biostratigraphic control were selected. References: Backman and Shackleton (1983), Burckle et al. (1978), Channell et al. (1985), Channell et al. (1988), Channell, Torii, and Hawthorne (this volume), Hsü et al. (1984), Keigwin (1982), Kent and Spariosu (1983), Saito et al.(1975), Tauxe et al. (1983a, 1983b), Weaver and Clement (1986), Zijderveld et al. (1986). Key: GM: Globorotalia margaritae, GN: G. nepenthes, GP: Globorotalia puncticulata, GB: Globorotalia bononiensis, GI: Globorotalia inflata, RP: $R$. pseudoumbilica, S: Sphaeroidinellopsis spp., CM: Calcidiscus macintyrei, NP: $N$. pachyderma (left coiling), DA: D. asymmetricus, DT: D. tamalis, DP: D. pentaradiatus, DS: D. surculus, DB: D. brouweri, GT: Globorotalia truncatulinoides, GO: G. oceanica s.1.

2. Globorotalia conomiozea FAD (Tortonian/Messinian boundary): This event is the suggested marker for the Tortonian/Messinian boundary, but it is unsatisfactory as such because of the rarity of this species in the open ocean. In the Blind River section (New Zealand), the FAD of Globorotalia conomiozea coincides with a carbon isotopic shift and with Chron 6r1 (Chron 3Ar) (Loutit and Kennett, 1979). More recent data from Blind River places both the FAD and the isotopic shift slightly earlier in Chron 6n (Chron 3B) (Edwards, 1987). The widespread carbon isotopic shift recognized in open ocean deep-sea cores usually occurs in Chron 6r1 (Chron 3Ar) (Haq et al., 1980). It has been argued that the Tortonian/Messinian bound- ary should coincide with this event and lie in Chron 6r1 (Chron 3Ar) (Berggren et al., 1985; Hsü, 1986). In western Morocco, the isotopic shift can be correlated to Chron 6n (Chron 3B) (Moreau et al., 1985; Hodell, pers. comm., 1988). In the Mediterranean itself, Van der Zwann and Gudjonsson (1986) recognize an isotopic shift in several sections close to the FAD of Globorotalia conomiozea. Langereis et al., (1984) have published good quality magnetostratigraphies from several sections across the Tortonian/Messinian boundary in Crete. The boundary, recognized by the FAD Globorotalia conomiozea, occurs within a reversed polarity zone interpreted, on the basis of pattern fit, as the middle part of Chron 5 (Chron 3A-1) (Langereis et al., 
1984). Although this pattern fit appears to be the optimal pattern fit, it does assume that the sedimentation rates were fairly constant. Hsü (1986) has pointed out that the sections contain frequent silty turbidites and has reinterpreted the magnetostratigraphy such that the FAD of Globorotalia conomiozea falls within Chron 6r1 (Chron 3Ar). The data from Site 654 (Fig. 5) indicate that the FAD of Globorotalia conomiozea occurs within a normal polarity zone. Channell, Torii, and Hawthorne (this volume) interpret this normal polarity zone to correspond to Chron 6n (Chron 3B), on the basis of polarity pattern fit. This correlation from Site 654 is consistent with the interpretation of new data from Blind River (Edwards, 1987) and with a section from western Morocco (Moreau et al., 1985), but not with the data from Crete (Langereis et al., 1984). The discrepancy may reflect problems in the taxonomy of $G$. conomiozea, rather than true diachroneity of the FAD.

3. Globorotalia margaritae FAD (MPL1-MPL2 boundary): The Mediterranean appearance of Globorotalia margaritae has been correlated to the GRTS at Sites 652 and 654, and in land sections at Singa (Zijderveld et al., 1986) and at Capo Spartivento (Channell et al., 1988). In each section, the event is associated with the Thvera subchron. Assuming constant sedimentation rates within the subchron, an average age of $4.65 \mathrm{Ma}$ is obtained for this event in the Mediterranean. This event is strongly diachronous with extra-Mediterranean sequences where the FAD of this species occurs either in the upper part of Chron 5 (North Atlantic, Leg 94) (Weaver and Clement, 1986) or the lowermost part of the Gilbert (Caribbean, Leg 68) (Keigwin, 1982). Therefore this event is Messinian in age in the open ocean, and early Pliocene in age in the Mediterranean (Fig. 9).

4. Globorotalia puncticulata FAD (MPL2-MPL3 boundary): This event has been correlated in land sections at Singa (Zijderveld et al., 1986), at Capo Spartivento (Channell et al., 1988 ) and at Site 652, to the upper part of the Nunivak subchron. At Site 652, this event occurs in Core 21R, immediately above an interval of no recovery which probably includes not only the true FAD, but also the Nunivak subchron. Nonetheless, the age of the Globorotalia puncticulata FAD in the Mediterranean can be well constrained at about $4.13 \mathrm{Ma}$. Berggren et al. (1985) estimated the age of the evolutionary appearance of Globorotalia puncticulata in the open ocean as $4.4 \mathrm{Ma}$. This would imply that the Globorotalia puncticulata FAD in the Mediterranean is a migration event and non-synchronous with that in the open ocean. However, in the North Atlantic sites of Leg 94, the Globorotalia puncticulata FAD is associated with the Nunivak subchron (Weaver and Clement, 1986), indicating synchroneity with the datum in the Mediterranean.

5. D. asymmetricus FCO (C. rugosus/R. pseudoumbilica boundary, and NN13/NN14 boundary): In the open ocean, the D. asymmetricus FAD is reported as occurring in the late Miocene (e.g., Bukry, 1973). In the Mediterranean, scattered rare specimens are reported in the earliest Pliocene. However, the first common and continuous occurrence (FCO) of this species provides a reliable and correlatable event in the Mediterranean (Müller, 1978; Rio et al., this volume). It occurs at Sites 652 and 654 consistently in the negative polarity interval just above the Cochiti subchron, at an age estimated to be 3.81-3.85 Ma. Berggren et al. (1985) estimated the age of the FAD of D. asymmetricus as $4.1 \mathrm{Ma}$, but this apparent diachroneity may be due to variations in the operational procedure for defining this event.

6. $R$. pseudoumbilica LAD ( $R$. pseudoumbilica/D. tamalis zonal boundary and NN15/NN16 boundary): We have already commented on the taxonomic problems associated with this species. Strongly contrasting ages have been reported for its extinction, ranging from about $2.5 \mathrm{Ma}$ to about $3.7 \mathrm{Ma}$. This range is probably a reflection of the taxonomic problem, rather than any well-founded lack of synchroneity in the biostratigraphic datum. Indeed, recently, several authors (see Fig. 9 and Berggren et al., 1985) have consistently indicated that the LAD of this species is associated with the upper part of the Gilbert Chron (Chron 2Ar). Our results from Sites 652 and 654, and from the section at Gela (Channell et al., 1985), confirm this correlation, and indicate that this event is most probably synchronous between the Mediterranean region and the open ocean. At Sites 652 and 654, the age of $R$. pseudoumbilica LAD obtained by assuming a constant sedimentation rate within the polarity zone in which it occurs, is about $3.66 \mathrm{Ma}$, which is slightly older than the age given by Backman and Shackleton (1983) for the open ocean $(3.56 \mathrm{Ma})$. At Gela, $R$. pseudoumbilica LAD is practically coincident with the Globorotalia margaritae LAD, at 3.43 $\mathrm{Ma}$. These inconsistencies may be due to irregularity of sediment accumulation rates rather than diachroneity of the event.

7. Globorotalia margaritae LAD (MPL3-MPL4 boundary): The widely quoted age for this event in the open ocean is $3.4 \mathrm{Ma}$ (Berggren et al., 1985). However, our compilation (Fig. 9) indicates that the Globorotalia margaritae LAD is a late Gilbert event, ranging in age from $3.5 \mathrm{Ma}$ to $3.8 \mathrm{Ma}$, both in the Mediterranean and in the open ocean. In the Mediterranean sections (Sites 652, 654, and Gela), it occurs in the late Gilbert at 3.53 Ma (Site 654), 3.44 Ma (Site 652), and 3.43 Ma (Gela). It should be noted that, in the Tyrrhenian area, the occurrence of Globorotalia margaritae can be sporadic toward the end of its range, and this may explain the scatter in age obtained for this datum and its variable juxtaposition with $R$. pseudoumbilica LAD. These two events are coincident in Gela and distinct at Sites 652 and 654 (Fig. 9). Additional work is needed to precisely date this event. Our best estimate at present is $3.5( \pm 0.06) \mathrm{Ma}$.

8. Sphaeroidinellopsis spp. LAD and Globorotalia bononiensis FAD (MPL4-MPL5 boundary): These events are discussed together because they occur very close to each other both in the Tyrrhenian Sea record and in land sections in southern Italy, and because the Globorotalia bononiensis FAD provides a means of approximately defining the MPL4/MPL5 boundary in sections in which the Sphaeroidinellopsis group is missing (Rio et al., 1984). It should be noted that in all Mediterranean sections so far investigated (viz., Sites 652,654 , and Gela), the Globorotalia bononiensis FAD slightly predates the Sphaeroidinellopsis spp. LAD (Fig. 9). In the Tyrrhenian record, at Sites 652 and 654, and at Gela, Globorotalia bononiensis FAD occurs in the Mammoth subchron, and the Sphaeroidinellopsis spp. LAD just above the top of the Mammoth subchron.

The Globorotalia bononiensis FAD is not commonly utilized in the open ocean, and is used only as a secondary marker in the Mediterranean zonation. On the other hand, the Sphaeroidinellopsis spp. LAD is a well established datum in extra-Mediterranean areas (Hays et al., 1969) where it ranges from 2.98 to 3.04 $\mathrm{Ma}$ (Fig. 9). At Gela and Sites 652 and 654, the inferred ages are $3.03,3.04$, and $3.08 \mathrm{Ma}$, respectively. Within the resolution of the available data, the Sphaeroidinellopsis spp. LAD appears synchronous between the Mediterranean and the open ocean. In the Mediterranean, our best estimates for the ages of Sphaeroidinellopsis spp. LAD and Globorotalia bononiensis FAD are $3.06( \pm 0.02)$ and $3.15( \pm 0.03) \mathrm{Ma}$, respectively.

9. Discoaster tamalis LAD (D. tamalis/D. pentaradiatus zonal boundary): This event is associated with the upper part of the Gauss Chron both in the Mediterranean and the open ocean. There is, however, considerable scatter, between 3.38 and $2.75 \mathrm{Ma}$, in the age of the event (Fig. 9). At least part of this scatter may be due to varying operational definitions of the event. Backman and Shackleton (1983) concluded that the LAD of D. tamalis is a rather distinct event with an age of $2.65( \pm$ 0.02 ) Ma. In the Mediterranean, Gela and Site 652 are the only sections in which it is possible to calibrate the $D$. tamalis LAD 
to the GRTS. In both sections, it occurs in the late Gauss, but precise age estimates are hampered by evidence for variable sedimentation rates and hiatuses in this interval. Our best estimates for the age of this event at Gela and Site 653 (Rio et al., this volume) are 2.63 and $2.6 \mathrm{Ma}$, respectively. Although additional work is necessary to estimate the age of this event in the Mediterranean, our age estimates are in close agreement with the estimate of Backman and Shackleton (1983) for the age of this event in the open ocean.

10. D. pentaradiatus LAD (D. pentaradiatus/D. brouweri zonal boundary): This event occurred in the earliest part of the Matuyama Chron both in the Mediterranean and in the open ocean, between approximately 2.45 and $2.35 \mathrm{Ma}$ (Fig. 9). This is consistent with the estimate of Backman and Pestiaux (1987). In the Mediterranean, the event coincides with the LAD of $D$. surculus.

11. Globorotalia inflata FAD (MPL5-MPL6 boundary): This event can be directly correlated to the GRTS only in one Mediterranean section (Gela) (Fig. 9), where it occurs at about 2.04 $\mathrm{Ma}$. This estimate is close to that of Rio et al. (1984), who estimated an age of $2.05 \mathrm{Ma}$ for this event in the Mediterranean using indirect scaling methods. In the North Atlantic sediments of Leg 94, Weaver and Clement (1986) obtained ages ranging from 2.01 to $2.25 \mathrm{Ma}$ for this event.

12. D. brouweri LAD (D. brouweri-D. productus zonal boundary, NN18/NN19 boundary): Most recent estimates of the age of this event indicate that it correlates to the base of the Olduvai subchron. The high resolution data from the open ocean of Backman and Shackleton (1983) place this event slightly below the base of the Olduvai, whereas the event tends to occur slightly above this reversal in the Mediterranean (Fig. 9). We consider that the $D$. brouweri LAD in the Mediterranean is in fact synchronous with that in the middle and low latitudes of the open ocean, and that slight differences may be due to different operational procedures in detecting of this event.

13. G. oceanica s.l. FAD and $G$. pachyderma (left coiling) FCO (Plio-Pleistocene boundary): These two events approximate to the Plio-Pleistocene boundary as recently defined in the Vrica section, where they occur slightly above the top of the Olduvai subchron. The $G$. oceanica s.l. FAD has been investigated in the open ocean (Rio et al., in press; Williams et al., in press), where it appears to be reasonably synchronous over wide areas with ages ranging from 1.57 to $1.65 \mathrm{Ma}$. At Site 652, this event occurs slightly above the Olduvai subchron (Fig. 9). G. pachyderma (left coiling) FCO occurs also slightly above the Olduvai at Sites 650 and 651 . These data confirm the established chronology of the Plio-Pleistocene boundary as recently defined in Italy (Tauxe et al., 1983a; Pasini et al., in press).

\section{CONCLUSIONS}

The correlation of Mediterranean calcareous plankton events to the GRTS using magnetostratigraphy from land sections, and from Leg 107, has placed Plio-Pleistocene calcareous plankton biostratigraphy on a sounder footing, by providing more reliable absolute age estimates for many of the more useful biostratigraphic events. Many of the plankton events in the Mediterranean are also known in the open ocean, although their synchroneity between the two environments has often been questioned. It is now becoming clear that most Plio-Pleistocene calcareous nannofossil events are broadly synchronous between the Mediterranean and the open ocean (Fig. 9). Mediterranean planktonic foraminiferal distributions tend to be more provincial, with events local to the Mediterranean. However, the ages of events such as Globorotalia inflata FAD, Globorotalia margaritae LAD and $G$. pachyderma (left coiling) FCO, are consistent with those inferred from Leg 94 in the North Atlantic (Weaver and Clement, 1986) and with other open ocean occurrences.
The FAD of Globorotalia margaritae is the notable exception. As has been previously suggested (e.g., Rio et al., 1984), this datum is diachronous between the Mediterranean and the open ocean by nearly $1 \mathrm{~m} . \mathrm{y}$. (Fig. 9). This event is commonly used as a marker for the Miocene/Pliocene boundary in the open ocean (e.g., Saito et al., 1975; Berggren et al., 1985), as it occurs close to the base of the Pliocene in the Mediterranean. This practice has resulted in the Miocene/Pliocene boundary being given an age of about 5.35 Ma (Berggren et al., 1985) which is about 450 k.y. too old.

The Zanclean/Piacenzian boundary occurs in the interval between the Globorotalia margaritae LAD and the Globorotalia puncticulata LAD, and can be closely correlated to the Gilbert/ Gauss boundary. The Plio-Pleistocene boundary, recognized by the $N$. pachyderma (left coiling) FCO, correlates closely to the top of the Olduvai subchron.

The correlation of the Messinian/Tortonian boundary both in the Mediterranean and in the open ocean remains problematic due, at least in part, to the unsatisfactory nature of the FAD of Globorotalia conomiozea as a marker for this boundary. This biostratigraphic event is not widely recognized in open ocean sections. At Site 654 , this event occurs in a normal polarity zone correlated to Chron 6n (Chron 3B). This is inconsistent with the result from Crete, where the event occurs within a reversed polarity zone correlated to Chron 5 (Chron 3A-1) (Langereis et al., 1984). However, the correlation at Site 654 of various events (Table 1) close to the Tortonian/Messinian boundary, including Globorotalia conomiozea FAD and Amaurolithus delicatus FAD, to the GRTS helps to refine the correlation of this boundary to the open ocean.

\section{ACKNOWLEDGMENTS}

This research has been supported by JOI/USSAC and by U.S. National Science Foundation grant 8804321.

\section{REFERENCES}

Backman, J., and Shackleton, N. J., 1983. Quantitative biochronology of Pliocene and Early Pleistocene calcareous nannoplankton from the Atlantic, Indian and Pacific Oceans. Mar. Micropaleontol., 8: 141-170.

Backman, J., and Pestiaux, P., 1987. Pliocene discoaster abundance variations at DSDP Site 606 , biochronology and paleoenvironmental implications. In Ruddiman, W. S., Kidd, R. B., et al., Init. Repts. DSDP, 94, Pt. 2: Washington (U.S. Govt. Printing Office), 903-910.

Berggren, W. A., Kent, D. V., and Van Couvering, J. A., 1985. Cenozoic geochronology. In Snelling, N. J. (Ed.) Geochronology and the Geologic Record, Geol. Soc. (London) Spec. Pap., 211-260.

Bossio, A., El Bied Rakich, K., Giannelli, L., Mazzei, R., Russo, A., and Salvatorini, G., 1976. Correlation de quelques sections stratigraphiques du Mio-Pliocène de la zone atlantique Maroc avec les stratotypes du Bassin Méditerranéen sur la base des Foraminifères planctoniques, Nannoplancton calcaire et Ostracodes. Atti. Soc. Tosc. Sci. Nat., Mem., 83:121-137.

Burckle, L. H., Gartner S., Opdyke, N. D., Sciarillo, J. R., and Shackleton, N. J., 1978. Paleomagnetics, oxygen isotopes and biostratigraphy of a late Pliocene section from the central Pacific: Biostratigraphic datum planes of the Pacific Neogene, IGCP 114:10-11.

Bukry, D., 1973. Low-latitude coccolith biostratigraphic zonation. In Haq B. U. (Ed.) Nannofossil Biostratigraphy. Stroudsburg, PA (Hutchinson and Ross Publ. Co.), 308-320.

Channell, J.E.T., Sprovieri, R., and Di Stefano, E., 1985. Magnetic stratigraphy and biostratigraphy of the Piacenzian (Upper Pliocene) at Monte San Nicola (Sicily). Geol. Soc. Am. Abstr. Programs, 542.

Channell, J.E.T., Rio, D., and Thunell, R., 1988. Miocene-Pliocene boundary magnetostratigraphy at Capo Spartivento, Calabria, Italy. Geology, 16:1096-1099.

Cita, M. B., 1975. The Miocene/Pliocene boundary: history and definition. In Saito, T., and Burckle, L. (Eds.) Late Neogene Epoch boundaries, New York (Micropaleontology Press), 1-30.

Colalongo, M. L., Di Grande, A., D'Onofrio, S., Giannelli, L., Iaccarino, S., Mazzei, R., Romeo, M., and Salvatorini, G., 1979. Stra- 
tigraphy of Late Neogene Italian sections straddling the Tortonian/ Messinian boundary. Boll. Soc. Paleontol. It., 18:258-302.

Cox, A., 1982. Magnetostratigraphic time scale. In Harland, W. B. et al., (Eds.), A Geologic Time Scale, Cambridge (Cambridge Univ. Press), 1-128.

D’Onofrio, S., Gianelli, L., Iaccarino, S., Morlotti, E., Romeo, M. Salvatorini, G., Sampo, M., and Sprovieri, R., 1975. Planktonic foraminifera from some Italian sections and the problem of the lower boundary of the Messinian. Boll. Soc. Paleontol. It., 14:177-196.

Edwards, A. R., 1987. Significant climatic vents in the Late Neogene marine strata of New Zealand. In Barron, J. A., and Blueford, J. R. (Eds.), Fourth International Congress on Pacific Neogene Stratigraphy, 26-27.

Feinberg, H., and Lorenz, H. G., 1970. Nouvelles donneés stratigraphiques sur le Miocène supérieur et le Pliocène du Maroc Occidental. Notes Serv. Géol. Maroc, 30:21-26.

Haq, B. U., Worsley, T. R., Burckle, L. H, Douglas, R. G., Keigwin, L. D. Jr., Opdyke, N. D., Savin, S. M., Sommer, M. A. II, Vincent, E., and Woodruff, F., 1980. Late Miocene marine carbon-isotopic shift and synchroneity of some phytoplanktonic biostratigraphic events. Geology, 8:427-431.

Haq, B. U., and Takayama, T., 1984. Neogene calcareous nannoplankton datum planes and their calibration to magnetostratigraphy. In Ikebe, N., and Tsuchi, R. (Eds.), Pacific Neogene Datum Planes. Tokyo (Univ. Tokyo Press).

Hays, J. D., Saito, T., Opdyke, N. D., and Burckle, L. M., 1969. Pliocene-Pleistocene sediments of the Equatorial Pacific: their paleomagnetic, biostratigraphic and climatic record. Geol. Soc. Am. Bull., 80:1481-1514.

Hsü, K. J., 1986. Unresolved problems concerning the Messinian Salinity Crisis. G. Geol., 47:203-212.

Hsü, K. J., LaBrecque, J. A., et al., 1984. Numerical ages of Cenozoic biostratigraphic datum levels: results of South Atlantic Leg 73 drilling. Geol. Soc. Am. Bull., 95:863-876.

Iaccarino, S., and Salvatorini, S., 1982. A framework of planktonic foraminiferal biostratigraphy for Early Miocene to Late Pliocene, Mediterranean area. Paleontol. Stratigr. Evol., 2:115-125.

Keigwin, L. D., 1982. Neogene planktonic foraminifers from deep sea drilling project Sites 502 and 503. In Press, W. L., and Gardner, J. V., et al., Init. Rep. DSDP, 68: Washington (U.S. Govt. Printing Office), 269-288.

Kent, D. V., and Spariosu, D. J., 1983. High resolution magnetostratigraphy of Caribbean Plio-Pleistocene deep-sea sediments. Palaeogeogr., Palaeoclimatol., Palaeoecol., 42:47-64.

Langereis, C. G., Zachariasse, W. J., and Zijderveld, J.D.A., 1984. Late Miocene magnetobiostratigraphy of Crete. Mar. Micropaleontol., 8: 261-281.

Loutit, T. S., and Kennett, J. P., 1979. Application of carbon isotope stratigraphy to late Miocene shallow marine sediments, New Zealand. Science, 204:1196-1199.

Martini, E., 1971. Standard Tertiary and Quaternary Calcareous Nannoplankton Zonation. In Farinacci, A. (Ed.). Proc. Planktonic Conf., 2nd, Roma, 2:739- 785 .

Moreau, M. G., Feinberg, H., and Pozzi, J. P., 1985. Magnetobiostratigraphy of a Late Miocene section from the Moroccan Atlantic margin. Earth Planet. Sci. Lett., 76:167-175.

Müller, C., 1978. Neogene Calcareous Nannofossils from the Mediterranean Leg $42 \mathrm{~A}$ of the Deep Sea Drilling Project. In Hsü, K. J., Montadert, L., et al., Init. Repts DSDP, 42, Washington (U.S. Govt. Printing Office), 727-751.

Nakagawa, H., Niitsuma, N., Kitamura, N., Matoba, Y., Takayama, T. and Asano, K., 1974. Preliminary results on magnetostratigraphy of Neogene and stage stratotype sections in Italy. Riv. It. Paleontol., $80: 615-630$

Nakagawa, H., Kitamura, N., et al., 1977. Magnetostratigraphic correlation of Neogene and Pleistocene between the Japanese Islands, central Pacific, and Mediterranean regions. In Saito, T., and Ujiie, H. (Eds.). Proceedings of the First International Congress on Pacific Neogene Stratigraphy, 285-310.

Pasini, G., Colalongo, M., and Sartoni, S., in press. Sedimentology, biostratigraphy, magnetostratigraphy, biochronology and radiometric dating of the Vrica section in Calabria (Italy). In Van Couvering, J. (Ed.) The Pliocene/Pleistocene Boundary: Definition and Worldwide Correlation. Cambridge (Cambridge Univ. Press).
Raffi, I., and Rio, D., 1979. Calcareous nannofossil biostratigraphy of DSDP Site 132-Leg 13 (Tyrrhenian Sea-Western Mediterranean). Riv. It. Paleontol. Stratigr., 85:127-172.

Rehault, J. P., Mascle, J., Fabbri, A., Moussat, E., and Thommeret, M., 1987. The Tyrrhenian Sea before Leg 107. In Kastens, K. A., Mascle, J., et al., Proc. ODP, Init. Repts., 107; College Station, TX (Ocean Drilling Program), 9-35.

Rio, D., 1982. The fossil distribution of Coccolithophore Genus Gephyrocapsa Kamptner and related Plio-Pleistocene chronostratigraphic problems. In Press, W. L., Gardner, J. V., et al., Init. Repts. DSDP, 68: Washington (U.S. Govt. Printing Office), 325-343.

Rio, D., Sprovieri, R. and Raffi, I., 1984. Calcareous plankton biostratigraphy and biochronology of the Pliocene-Lower Pleistocene succession of the Capo Rosello area, Sicily. Mar. Micropaleontol., 9: $135-180$.

Rio, D., Backman, J., and Raffi, I., in press. Calcareous nannofossil biochronology and the Plio-Pleistocene boundary. In Van Couvering, J. (Ed.) The Neogene/Quaternary Boundary. Cambridge (Cambridge Univ. Press).

Ryan, W.B.F., and Flood, J. D., 1972. Preliminary paleomagnetic measurements on sediments from the Ionian (Site 125) and Tyrrhenian (Site 132) Basins of the Mediterranean. In Ryan, W.B.F., Hsü, K. J., et al., Init. Repts. DSDP, 13, Washington (U.S. Govt. Printing Office), 599-604.

Ryan, W.B.F., Cita, M. B., Rawson, M., Dreyfus, Burckle, L. H., and Saito, T., 1974. A paleomagnetic assignment of Neogene stage boundaries and the development of isochronous datum planes between the Mediterranean, the Pacific and Indian Oceans in order to investigate the response of the world ocean to the Mediterranean "salinity crisis". Riv. It. Paleontol., 80:631-688.

Saito, T., Burckle, L. H., and Hays, J. D., 1975. Late Miocene to Pleistocene biostratigraphy of Equatorial Pacific Sediment. In Saito, T., and Burckle, L. H. (Eds.). Late Neogene Epoch Boundaries. Am. Mus. Nat. Hist., Micropaleontology Press, 226-244.

Sierro, F. J., 1985. The replacement of the Gr. menardii group by the Gr. miotumida group: An aid to recognising the Tortonian/Messinian boundary in the Mediterranean and adjacent Atlantic. Mar. Micropaleontol., 9:525-535.

Tauxe, L., Opdyke, N. D., Pasini, G., and Elmi, C., 1983a. The paleomagnetism of the Vrica section (Calabria, Italy), the proposed Pliocene/Pleistocene boundary-stratotype section. Nature, 304:125-129.

Tauxe, L., Tucker, P., Petersen, N. P., and LaBrecque, J. L., 1983b. The magnetostratigraphy of Leg 73 sediments. Palaeogeogr., Palaeoclimatol., Palaeoecol., 42:65-90.

Tjalsma, R. C., 1971. Stratigraphy and foraminifera of the Neogene of the eastern Guadalquivir Basin (southern Spain). Utrecht Micropaleontol. Bull., 4: 1-161.

Van der Zwaan, G. J., and Gudjonsson, L., 1986. Middle Miocene-Pliocene stable isotope stratigraphy and paleoceanography of the Mediterranean. Mar. Micropaleontol., 10:71-90.

Weaver, P.P.E., and Clement, B. M., 1986. Synchroneity of Pliocene Plankton Foraminiferal Datums in the North Atlantic. Mar. Micropaleontol., 10:295-307.

Wernli, R., 1980. Le Messinien a "Globorotalia conomiozea" foraminifère planctonique) de la cõte méditerranéenne. Eclogae Geol. Helv., 73:71-93.

Williams, D. F., Thunell, R. C., Tappa, E., Rio, D., Raffi, I., in press. Chronology of the Pleistocene oxygen isotope record: $0-1.88 \mathrm{my}$ B.P. Palaeogeogr., Palaeoclimatol., Palaeoecol., 64: .

Zachariasse, W. J., 1975. Planktonic foraminiferal biozonation of the Late Neogene of Crete (Greece). Utrecht Micropaleontol. Bull., 11: 1-171.

1979. The origin of Globorotalia conomiozea in the Mediterranean and the value of its entry level in biostratigraphic correlations. Ann. Geol. Pays Hellen., 1281-1292. (VIIth International Congress on Mediterranean Neogene, Athens)

Zijderveld, J.D.A., Zachariasse, J. W., Verhallen, P.J.J.M., and Hilgen, F. J., 1986. The age of the Miocene-Pliocene boundary. Newsl. Stratigr., 16:169-181.

Date of initial receipt: 1 August 1988

Date of acceptance: 17 January 1989

Ms 107B-180 